\title{
The Effects of Age and Body Mass Index on Blood Glucose, Blood Cholesterol, and Blood Pressure in Adult Women by Riza Fikriana
}

Submission date: 25-Nov-2020 02:55PM (UTC+0800)

Submission ID: 1456846134

File name: The_Effects_of_Age_and_Body_Mass_Index_on_Blood_Glucose,.pdf (453.71K)

Word count: 3239

Character count: 16934 


\title{
The Effects of Age and Body Mass Index on Blood Glucose, Blood Cholesterol, and Blood Pressure in Adult Women
}

\author{
Riza Fikriana ${ }^{1}$, Shrimarti Rukmini Devy ${ }^{2}$ \\ ${ }^{\prime}$ Doctoral Program of Public Health, ${ }^{2}$ Department of Health Promotion and Behaviour Science, Faculty of \\ Public Health, University of Airlangga, Surabaya, Indonesia
}

\begin{abstract}
Introduction: The risk factors of cardiovascular disease include having a high body mass index, hyperglycemia, hypercholesterolemia and increased blood pressure. The purpose of this study was to analyse the effects of age and body mass index (BMI) on blood glucose, blood cholesterol and blood pressure in adult women.

Method: An analytical observation using a cross-sectional method was employed as the study design. The study recruited 60 women aged between 30 to 60 years old to participate, using a purposive sampling technique. The data was analysed using univariate analysis and path analysis.

Result: Age and BMI showed as having the strongest direct effect 3 on the blood pressure. Age also had a direct effect on blood glucose level and blood cholesterol level. The effect of age on blood glucose and blood cholesterol was also mediated by BMI.

Conclusion: Being of an older age had a direct effect on increased blood glucose, blood cholesterol, and blood pressure, while a higher BMI had a direct effect on increased blood pressure. As women get older, maintaining a normal BMI is beneficial to preventing the increase of their blood glucose, blood cholesterol and blood pressure.
\end{abstract}

Keywords: age, body mass index, blood glucose, blood cholesterol, blood pressure

\section{INTRODUCTION}

Cardiovascular disease is a public health problems and the leading cause of death in both developed and developing countries. ${ }^{1,2}$ Globally, the number of deaths due to cardiovascular disease is estimated to have increased from 16.7 million in 2002 to 23.3 million in $2030 .^{3}$ In Indonesia, coronary heart disease is the second leading cause of death after stroke, contributing to $12.9 \%$ of the overall mortality rate. ${ }^{4}$

Several risk factors have been identified as a contributing factor to cardiovascular disease including

\section{Corresponding Author:}

Riza Fikriana

Doctoral Program of Public Health,

Faculty of Public Health, Universitas Airlangga,

Mulyorejo, Surabaya, Indonesia

Email: riza.fikriana-2017@fkm.unair.ac.id age, increased body mass index, hyperglycemia, hypercholesterolemia and increased blood pressure. ${ }^{2}$ 5-8 The risk of cardiovascular disease in females is greater than in males, with the influence of conventional factors such as high blood pressure, high cholesterol, diabetes, excessive body weight, and factors related to psychosocial condition and socioeconomic status. ${ }^{9}$ In addition, hormonal changes throughout a woman's stages of life that affect the cardiac conduction system and the structure and function of the blood vessels, and systemic inflammation could cause cardiovascular disease. ${ }^{10,11}$ The purpose of this study was to analyse the effect of age and body mass index (BMI) on blood glucose, blood cholesterol and blood pressure in adult women.

\section{METHOD}

Study design, setting, and sample size: This study employed an analytical observational design method with a cross-sectional method. The study was conducted 
in Malang district, East Java, Indonesia. Using a purposive sampling method, 60 women aged between 30 to 60 years old were recruited to participate in the study.

Variables and the instrument of the data collection: There were five variables in the study, including age, BMI, blood glucose, blood cholesterol, and blood pressure as described below.

a. Age: The data of age was obtained from the sociodemographic characteristics of the respondents stated during the data collection. Other sociodemographic data included marital status, employment status and co-morbidity.

b. Body mass index (BMI): The body mass index was obtained from the measurement of body weight $(\mathrm{kg})$ and height $(\mathrm{m})$. The formula to calculate the BMI is as follow: (weight $(\mathrm{kg}) /$ weight $(\mathrm{m}))^{2}$. BMI was classified as underweight (BMI $<20 \mathrm{~kg} / \mathrm{m}^{2}$, normal $\left(\mathrm{BMI}=20-24.9 \mathrm{~kg} / \mathrm{m}^{2}\right.$ ), overweight $\left(\mathrm{BMI}=25-29.9 \mathrm{~kg} / \mathrm{m}^{2}\right)$, and obesity $\left(\mathrm{BMI} \geq 30 \mathrm{~kg} / \mathrm{m}^{2}\right)$.

c. Blood glucose: The blood glucose was measured based on the capillary blood glucose level $(\mathrm{mg} /$ dl) using a glucose meter. For the purpose of this study, blood glucose was measured from a random glucose test. A blood glucose level of less than $200 \mathrm{mg} / \mathrm{dl}$ was categorised as normal and a level of $200 \mathrm{mg} / \mathrm{dl}$ or higher was classified as hyperglycemia.

d. Blood cholesterol: Blood cholesterol was measured from the total blood cholesterol level obtained from peripheral blood $(\mathrm{mg} / \mathrm{dl})$ using a finger-stick cholesterol test. The blood cholesterol level was considered to be normal at less than $200 \mathrm{mg} / \mathrm{dl}$, and hypocholesteremic at $200 \mathrm{mg} / \mathrm{dl}$ or higher.

e. Blood pressure: The blood pressure level was measured using a sphygmomanometer. The results of the Systolic Blood Pressure (SBP) and Dyastolic Blood Pressure (DBP) measurements of each study participant were recorded on an observation sheet. Using the Joint National Committee's 8 guidelines, the blood pressure level was categorised as normal for the $\mathrm{SBP}<120$ $\mathrm{mmHg}$ and $\mathrm{DBP}<80 \mathrm{mmHg}$, pre-hypertension for the SBP $120-139 \mathrm{mmHg}$ and DBP $80-89$ $\mathrm{mmHg}$, hypertension stage 1 for the SBP 140 - $159 \mathrm{mmHg}$ and DBP $90-99 \mathrm{mmHg}$, and hypertension stage 2 for the $\mathrm{SBP} \geq 160 \mathrm{mmHg}$ and $\mathrm{DBP} \geq 100 \mathrm{mmHg}$. ${ }^{12}$
Ethical consideration and the data collection: Before the data collection, all of the study participants were provided with information about the study and the right to withdraw at any time. A written informed consent was submitted by participants to indicate agreement to participate in the study. After filling in the questionnaire with their age, marital status, and current employment status, participants were measured for their blood pressure level, blood glucose level and blood cholesterol level.

\section{DATA ANALYSIS}

The data was analysed using descriptive analysis to describe the sociodemographic characteristics and the clinical characteristics of the participants. The data was then analysed using path analysis.

\section{RESULTS}

Sociodemographic and clinical characteristics of the study participants: As shown in Table 1, more than half of the subjects $(63.3 \%)$ were aged between 30 to 45 years old. The majority of the women were married $(88.3 \%)$ and unemployed (68.3\%). Based on their clinical status, the majority of them did not have diabetes mellitus as a co-morbidity as indicated by the high percentage of women $(91.7 \%)$ with normal random blood glucose level. The majority of the subjects had a normal BMI (45\%). Most of the study subjects had a normal blood cholesterol level (51.7\%), and normal blood pressure (35\%).

Table 1: Sociodemographic characteristics and clinical characteristics of the study participants

\begin{tabular}{|c|c|c|c|}
\hline \multirow{2}{*}{ Characteristics } & \multicolumn{2}{c|}{ Total } \\
\cline { 2 - 4 } & N & $\%$ \\
\hline \multicolumn{2}{|c|}{ Socio-demographic characteristics } \\
\hline \multirow{2}{*}{ Age (years) } & $30-45$ & 38 & 63.3 \\
\cline { 2 - 4 } & $\geq 46$ & 22 & 36.7 \\
\hline \multirow{2}{*}{ Marital status } & Married & 53 & 88.3 \\
\cline { 2 - 4 } & $\begin{array}{c}\text { Single/Divorce/ } \\
\text { Widowed }\end{array}$ & 7 & 11.7 \\
\hline \multirow{2}{*}{$\begin{array}{c}\text { Employment } \\
\text { status }\end{array}$} & Employed & 19 & 31.7 \\
\cline { 2 - 4 } Clinical characteristic & 41 & 68.3 \\
\hline $\begin{array}{c}\text { Diabetes } \\
\text { mellitus as } \\
\text { co-morbidity }\end{array}$ & Yes & 5 & 8.3 \\
\cline { 2 - 4 } & No & 55 & 91.7 \\
\hline
\end{tabular}


Conted...

\begin{tabular}{|c|c|c|c|}
\hline \multirow{4}{*}{$\begin{array}{c}\text { Body mass } \\
\text { index }\end{array}$} & Underweight & 7 & 11.6 \\
\cline { 2 - 4 } & Normal & 27 & 45.0 \\
\cline { 2 - 4 } & Overweight & 15 & 25.0 \\
\cline { 2 - 4 } & Obesity & 11 & 18.4 \\
\hline \multirow{2}{*}{$\begin{array}{c}\text { Blood } \\
\text { glucose }\end{array}$} & Normal & 55 & 91.7 \\
\cline { 2 - 4 } $\begin{array}{c}\text { Blood } \\
\text { cholesterol }\end{array}$ & Hyperglycemia & 5 & 8.3 \\
\hline \multirow{3}{*}{$\begin{array}{c}\text { Blood } \\
\text { pressure }\end{array}$} & Normal & 31 & 51.7 \\
\cline { 2 - 4 } & Hypercholesterolemia & 29 & 48.3 \\
\cline { 2 - 4 } & Normal & 21 & 35.0 \\
\cline { 2 - 4 } & Hypertension stage 1 & 14 & 23.3 \\
\cline { 2 - 4 } & Hypertension stage 2 & 6 & 10.0 \\
\hline
\end{tabular}

Path analysis: As shown in Figure 3, the diagram path presented the results of the path analysis on the effects of age and BMI on blood glucose, blood cholesterol and blood pressure among the women participating in the study. There were four paths with significant relationships. The first significant direct effect was in age (X1. Usia) $\rightarrow$ blood glucose (Y1.GD). The second significant direct effect was age (X1. Usia) $\rightarrow$ blood cholesterol (Y2.KD). The third significant direct effect was age (X1. Usia) $\rightarrow$ blood pressure (Y3.TD). The fourth significant direct effect was shown in BMI (X2. IMT) $\rightarrow$ blood pressure (Y3.TD).

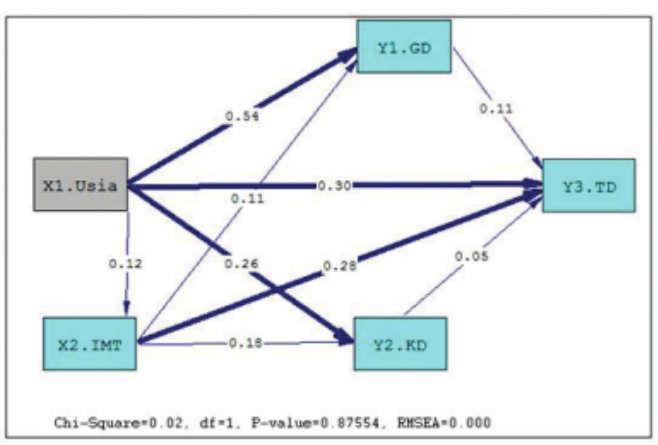

Figure 1: Results of the path analyses with their beta coefficient value

Table 2 presents the results of the path analysis displaying the effect values of age related to blood glucose, blood cholesterol and blood pressure. Each path described the direct or indirect effect of age on blood glucose, blood cholesterol and blood pressure. BMI was entered as the mediating variable.

Table 2: The path effect value of age on blood glucose, blood cholesterol, and blood pressure

\begin{tabular}{|c|c|c|c|}
\hline No. & Path of variable & Effect value & Total effect \\
\hline 1. & Age $\rightarrow$ Blood Glucose & 0.54 & \multirow{2}{*}{0.553} \\
\hline 2. & Age $\rightarrow$ BMI $\rightarrow$ Blood Glucose & $0.12 \times 0.11=0.0132$ & \\
\hline 3. & Age $\rightarrow$ Blood cholesterol & 0.26 & \multirow{2}{*}{0.282} \\
\hline 4. & Age $\rightarrow$ BMI $\rightarrow$ Blood cholesterol & $0.12 \times 0.18=0.0216$ & \\
\hline 5. & Age $\rightarrow$ Blood Pressure & 0.30 & \multirow{6}{*}{0.409} \\
\hline 6. & Age $\rightarrow$ Blood Glucose $\rightarrow$ Blood pressure & $0.54 \times 0.11=0.0594$ & \\
\hline 7. & Age $\rightarrow$ Blood cholesterol $\rightarrow$ Blood Pressure & $0.26 \times 0.05=0.013$ & \\
\hline 8. & Age $\rightarrow$ BMI $\rightarrow$ Blood Cholesterol $\rightarrow$ Blood Pressure & $0.12 \times 0.18 \times 0.05=0.0011$ & \\
\hline 9. & Age $\rightarrow$ BMI $\rightarrow$ Blood Glucose $\rightarrow$ Blood Pressure & $0.12 \times 0.11 \times 0.11=0.0015$ & \\
\hline 10. & Age $\rightarrow$ BMI $\rightarrow$ Blood Pressure & $0.28=0.034$ & \\
\hline
\end{tabular}

The first path showed a direct effect between age (X1) and blood glucose (Y1), while the second path had BMI as the mediator variable (X2). The effect value in the first path was 0.54 . The value of this effect was unidirectional. As the women got older, their blood glucose levels tended to increase by 0.54 times. In the second path, the effect value was 0.013 . The direction showed an order of effect that indicated that older age with the BMI increase as the mediation would increase the blood glucose level by 0.013 times. The total effect of the relationship between age and blood glucose was 0.553 times.

The third and fourth paths showed the effect between age (X1) and blood cholesterol (Y2). The third path presented a direct path, while the fourth path had a direction with BMI as the mediating variable (X2). The effect value of the third path was 0.26 , while the 
fourth path was 0.0216 after being mediated by BMI. The total effect of the relationship between women's age and blood cholesterol level was 0.282 . This effect value indicated the unidirectional path which explained that growing older would lead women to have an increased blood cholesterol level by 0.282 times.

The paths from the fifth to the tenth were the pathway between age (X1) and the blood pressure variable (Y3). While the fifth path had a direct line between age and blood pressure level, the sixth path up to the tenth path were each mediated by BMI, blood glucose, and blood cholesterol respectively. The total of the effect value from the fifth to the tenth paths was 0.409 . The unidirectional effect value means that the increased age of women would lead to the increasing blood pressure level by 0.409 times.

This finding indicates that the women's age had a strong significant effect on blood glucose, blood pressure, and blood cholesterol respectively. The women's BMI had a significant effect on blood pressure.

\section{DISCUSSION}

Age was shown to have a strong effect on blood glucose level, blood pressure level, and blood cholesterol level. The blood glucose level tends to rise along with an increase in age. The results of this study confirmed the findings of previous studies. ${ }^{13,14}$ Aging has a correlation to the changes in glucose metabolism in the blood system, including insulin resistance and cell dysfunction. ${ }^{15}$, 16 The effectiveness of insulin could be decreasing due to an increase in abdominal fat mass, low physical activity, mitochondrial dysfunction, and hormonal changes. ${ }^{17,18}$

The strong effect of age on the women's blood pressure level has been shown in the present study. This finding was consistent with previous studies that reported that increased blood pressure level was significantly associated with increasing age. ${ }^{19-21}$ Aging causes changes in the structure of the arteries, so then the arteries become more rigid..$^{22}$ The increase in blood pressure may occur due to an unhealthy lifestyle, such as a high salt intake and high sugar ${ }_{3}$ consumption. ${ }^{23} \mathrm{~A}$ high level of salt in diet can cause changes in vascular smooth muscle cells, which results in the accumulation of collagen in the walls of the arteries, thus increasing arterial stiffness. ${ }^{24}$ For women, approaching the menopausal period cause a greater risk of increased blood pressure level than men. The mechanism of the blood pressure rise involves ${ }_{3}$ multiple factors such as decreased oestrogen levels, oxidative stress, endothelial dysfunction, and the influence of the renin angiotensin system and sympathetic activation..$^{25}$

Another strong effect was also found between the women's age and blood cholesterol level in this study. The aging process results in changes in the cholesterol metabolism of the blood. These changes cause an increase in Low Density Lipoprotein (LDL) cholesterol. The balance between intake, synthesis, absorption, and excretion affects the cholesterol metabolism of the human body. ${ }^{26}$

Body Mass Index (BMI) affects blood pressure level. This finding supports the results of previous studies that illustrated the significant relationship between BMI and blood pressure. ${ }^{19}$, ${ }^{23}$ A high level of BMI affects blood pressure. Practicing a healthy lifestyle and controlling bodily weight should be encouraged in order to prevent an increase in blood pressure..$^{25,27,28}$

\section{CONCLUSION}

Age has a significant effect on blood glucose, blood pressure, and blood cholesterol, while BMI has a significant effect on blood pressure. Aging puts 2 Women at a greater risk of having an increased level of blood glucose, blood pressure, and blood cholesterol. The risk escalates for older women with a high BMI. To maintain a normal level of blood sugar, blood cholesterol, and blood pressure, the risk factors should be controlled. While aging is inevitable, BMI level can be managed by practicing a healthy lifestyle such as reducing fat, salt, and sugar intake in their diet, promoting physical activity, and maintaining a normal body weight.

Ethical Clearance: Ethical approval was granted by the School of Public Health in Airlangga University, Surabaya.

\section{Source of Funding: self funding.}

Conflict of Interest: Authors declared that we have no conflict of interest. 


\section{REFERENCES}

1. Nangia R, Singh H, Kaur K. Prevalence of cardiovascular disease (CVD) risk factors. medical journal armed forces india. 2016;72(4):315-9.

2. Balakumar P, Maung-U K, Jagadeesh G. Prevalence and prevention of cardiovascular disease and diabetes mellitus. Pharmacological research. 2016;113:600-9.

3. Mathers CD, Loncar D. Projections of global mortality and burden of disease from 2002 to 2030. PLoS medicine. 2006;3(11):e442.

4. MoH. Penyakit Jantung Penyebab Kematian Tertinggi, Kemenkes Ingatkan CERDIK (the cardiovascular disease is the highestcause of death, the health minister remind to do CERDIK) Jakarta: Kemenkes RI; 2017 [Available from: http:// www.depkes.go.id/article/view/17073100005/ penyakit-jantung-penyebab-kematian-tertinggikemenkes-ingatkan-cerdik-.html.

5. Corella D, Ordovás JM. Aging and cardiovascular diseases: The role of gene-diet interactions. Ageing research reviews. 2014;18:53-73.

6. Tragante V, Barnes MR, Ganesh SK, Lanktree MB, Guo W, Franceschini N, et al. Gene-centric meta-analysis in 87,736 individuals of European ancestry identifies multiple blood-pressure-related loci. The American Journal of Human Genetics. 2014;94(3):349-60.

7. Lamelas P, Schwalm J, Leong D, Jolly S, Mehta S, Bangdiwala S, et al. Varying Effects of Body Mass Index and Mortality in Different Risk Groups. The American Journal of Cardiology. 2018.

8. World Health Organization. Global atlas on cardiovascular diseases prevention and control. Geneva: WHO; 2011.

9. Möller-Leimkühler AM. Gender differences in cardiovascular disease and comorbid depression. Dialogues in Clinical Neuroscience. 2007;9(1):7183.

10. Li J, Song C, Li C, Liu P, Sun Z, Yang X. Increased risk of cardiovascular disease in women with prior gestational diabetes: A systematic review and meta-analysis. Diabetes research and clinical practice. 2018;140:324-38.
11. Leonard EA, Marshall RJ. Cardiovascular Disease in Women. Primary Care: Clinics in Office Practice. 2018;45(1):131-41.

12. Shrout T, Rudy DW, Piascik MT. Hypertension update, JNC8 and beyond. Current opinion in pharmacology. 2017;33:41-6.

13. Ko GT, Wai HP, Tang JS. Effects of age on plasma glucose levels in non-diabetic Hong Kong Chinese. Croatian medical journal. 2006;47(5):709-13.

14. Suastika K, Dwipayana P, Saraswati IMR, Kuswardhani T, Astika N, Putrawan IB, et al. Relationship between age and metabolic disorders in the population of Bali. Journal of Clinical Gerontology and Geriatrics. 2011;2(2):47-52.

15. Kalyani RR, Egan JM. Diabetes and altered glucose metabolism with aging. Endocrinology and Metabolism Clinics. 2013;42(2):333-47.

16. Park MH, Kim DH, Lee EK, Kim ND, Im DS, Lee $\mathrm{J}$, et al. Age-related inflammation and insulin resistance: a review of their intricate interdependency. Archives of pharmacal research. 2014;37(12):1507-14.

17. Karakelides H, Irving BA, Short KR, O'brien P, Nair KS. Age, obesity, and sex effects on insulin sensitivity and skeletal muscle mitochondrial function. Diabetes. 2009.

18. Goulet ED, Hassaine A, Dionne IJ, Gaudreau P, Khalil A, Fulop T, et al. Frailty in the elderly is associated with insulin resistance of glucose metabolism in the postabsorptive state only in the presence of increased abdominal fat. Experimental gerontology. 2009;44(11):740-4.

19. Boledovičová M, Hendl J, Lišková L, Slamková A, Matoulek M, Stránská Z, et al. Blood pressure relation to body composition and age: analysis of a nurse-led investigation and consultation program. Medical science monitor: international medical journal of experimental and clinical research. 2013; 19:612.

20. Jung C-H, Jung SH, Lee B, Rosenberg M, Reaven GM, Kim SH. Relationship among age, insulin resistance, and blood pressure. Journal of the American Society of Hypertension. 2017;11(6):359-65. e2. 
21. Sun H, Sun M. Age-and gender-dependent associations of blood pressure and serum sodium and potassium - renal and extrarenal regulations. Journal of the American Society of Hypertension. 2018;12(5):392-401.

22. Pinto E. Blood pressure and ageing. Postgraduate medical journal. 2007;83(976):109-14.

23. Fujisawa M, Ishimoto Y, Chen W, Manuaba IIB, del Saz EG, Okumiya K, et al. Correlation of systolic blood pressure with age and body mass index in native Papuan populations. Hypertension Research. 2012;35(9):959.

24. Safar ME. Systolic hypertension in the elderly: arterial wall mechanical properties and the reninangiotensin-aldosterone system. Journal of hypertension. 2005;23(4):673-81.

25. Channanath AM, Farran B, Behbehani K, Thanaraj TA. Association between body mass index and onset of hypertension in men and women with and without diabetes: A crosssectional study using national health data from the State of Kuwait in the Arabian Peninsula. Bmj Open. 2015;5(6):e007043.

26. Morgan A, Mooney KM, Wilkinson SJ, Pickles N, Mc Auley MT. Cholesterol metabolism: A review of how ageing disrupts the biological mechanisms responsible for its regulation. Ageing research reviews. 2016;27:108-24.

27. Dua S, Bhuker M, Sharma P, Dhall M, Kapoor $\mathrm{S}$. Body mass index relates to blood pressure among adults. North American journal of medical sciences. 2014;6(2):89.

28. Vuvor F. Correlation of body mass index and blood pressure of adults of 30-50 years of age in Ghana. Journal of Health Research and Reviews. 2017;4(3):115. 
The Effects of Age and Body Mass Index on Blood Glucose, Blood Cholesterol, and Blood Pressure in Adult Women

ORIGINALITY REPORT

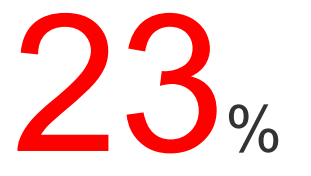

SIMILARITY INDEX
$19 \%$

INTERNET SOURCES
$16 \%$

PUBLICATIONS
$2 \%$

STUDENT PAPERS

PRIMARY SOURCES

1 repo.unand.ac.id Internet Source

2 Zhao Wen. "Depression and hypertension among Chinese nonagenarians and centenarians", International Journal of Geriatric Psychiatry, 06/2010 Publication

3 Frederick M. Wekesah, Martin K. Mutua, Daniel Boateng, Diederick E. Grobbee et al. "Comparative performance of pooled cohort equations and Framingham risk scores in cardiovascular disease risk classification in a slum setting in Nairobi Kenya", IJC Heart \& Vasculature, 2020

\section{Publication}

4 www.tandfonline.com Internet Source 
7 journals.Iww.com

8 qa.savannahnow.com

9 familydoctor.org Internet Source

10 Palacios, S.. "Advances in hormone replacement therapy with drospirenone, a unique progestogen with aldosterone receptor antagonism", Maturitas, 20061120 Publication

11 www.jphres.org Internet Source

12 "Abstracts", The Journal of Maternal-Fetal \&

Neonatal Medicine, 2009

Publication

13 www.ncbi.nlm.nih.gov

Internet Source

14 www.cancer-cn.mgloves.com 
16 www.endocrine-abstracts.org

17 Savitha Prabhu, Linu Sara George, G.

Shyamala, Tessy Treesa Jose, Anice George.

"The effect of a prenatal psychosocial education

program on postnatal depression, stress, and

parenting self-efficacy in women in South India -

A study protocol for a randomised controlled

trial", Mental Health \& Prevention, 2020

Publication

18

Lucas A. C. Souza, Fatima Trebak, Veena

Kumar, Ryousuke Satou, Patrick G. Kehoe, Wei

Yang, Whitney Wharton, Yumei Feng Earley.

"Elevated cerebrospinal fluid sodium in

hypertensive human subjects with a family

history of Alzheimer's disease", Physiological

Genomics, 2020

Publication

19 J G Schanen. "Asthma and incident

cardiovascular disease: the Atherosclerosis Risk

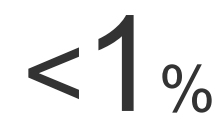
in Communities Study", Thorax, 2005

Publication

20

www.dovepress.com

Internet Source

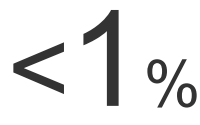

21 genesishcc.com

Internet Source 
22 accucheckhome.com

\section{3 www.e-reading.me}

24 medical-dictionary.thefreedictionary.com

25 cochranelibrary-wiley.com

Internet Source

26 www.uhahealth.com

27 diabcure.blogspot.com

28 m.scirp.org

Internet Source

29 www.cvja.co.za

30 www.lifeextension.com Internet Source

31 Csaba Farsang. "Indications for and utilization of angiotensin receptor II blockers in patients at high cardiovascular risk", Vascular Health and Risk Management, 2011

Publication

Marla Rogers, Mark Lemstra. "The Healthy 
32 Weights Initiative: a community-based obesity

reduction program with positive impact on depressed mood scores", Psychology Research and Behavior Management, 2016

Publication

33

"Proceedings of the Andalas International Public Health Conference 2017", BMC Public Health, 2017

Publication

34 journals.physiology.org Internet Source

36 JAE-YOUNG UM, HYUNG-MIN KIM, SUNGWON MUN, YUNG-SUN SONG, SEUNG-HEON HONG. "INTERLEUKIN-1 RECEPTOR ANTAGONIST GENE POLYMORPHISM AND TRADITIONAL CLASSIFICATION IN OBESE WOMEN", International Journal of

Neuroscience, 2009

Publication

Mohammed Elimam Ahamed Mohammed, Safar Alshahrani, Gaffar Zaman, Magbool Alelyani, Ibrahim Hadadi, Mustafa Musa. "Lipid profile, random blood glucose and carotid arteries thickness in human male subjects with different ages and body mass indexes", The Aging Male, 
38 Takshita Sookan. "Effects of a resistance training programme in people living with HIV in Zimbabwe", Sport Sciences for Health, 2020

Publication

39 Camila Manrique-Acevedo, Bhavana

Chinnakotla, Jaume Padilla, Luis A. MartinezLemus, David Gozal. "Obesity and cardiovascular disease in women", International Journal of Obesity, 2020

Publication 


\section{The Effects of Age and Body Mass Index on Blood Glucose, Blood Cholesterol, and Blood Pressure in Adult Women}

GRADEMARK REPORT

FINAL GRADE

10

PAGE 1

PAGE 2

PAGE 3

PAGE 4

PAGE 5

PAGE 6
GENERAL COMMENTS

Instructor 